\title{
Warning! The use of meteorological information during a flash-flood warning process
}

\author{
L. Créton-Cazanave \\ Institut de Géographie Alpine, Université de Grenoble, 14bis avenue Marie Reynoard, 38000 Grenoble, France \\ Received: 30 December 2008 - Revised: 15 March 2009 - Accepted: 10 April 2009 - Published: 26 May 2009
}

\begin{abstract}
Warning is a key issue to reduce flash floods impacts. But, despite many studies, local and national authorities still struggle to issue good flash floods warnings. We will argue that this failure results from a classical approach of warnings, based on a strict separation between the assessment world and the action world. We will go further than the previous criticisms (Pielke and Carbone, 2002) and show that forecasters, decision makers, emergency services and local population have quite similar practices during a flash-flood warning. Focusing on the use of meteorological information in the warning process, our case study shows that more research about the real practices of stakeholders would be another step towards integrated studies.
\end{abstract}

\section{Introduction}

Over the last decades, flash floods caused life and property losses, all over the world (for example in France, 23 casualties in the 2002 Gard event). Linked with extreme rainfall events, flash floods represent a major threat, likely to become more important due to the anticipated climate change. In western countries, many tools help to reduce flash-floods impacts: flood control structures, education, land use planning, warning... Among them, warning remains an effective way to reduce losses during flash-floods.

Despite of the great improvement of the past 30 years, flash flood warnings continue to be criticized for their inefficiency or inaccuracy (Sorensen, 2000). The September 2005 event in the Gard département of France gave a new example of these criticisms (Hornus and Martin, 2005).

Many studies emphasize the need for an integrated approach about the warning process, from forecast improvements to societal issues (e.g. Demuth et al., 2007; Drobot and Parker, 2007). Indeed the so-called classical warning approach tends to separate the warning process into two distincts worlds, and thus misses a part of the warning process. Our study of the flash-flood warning process in the Vidourle catchment, in the Gard département (South of France), allows us to emphasize the need for an integrated approach that rely on a common study framework for all stakeholders.

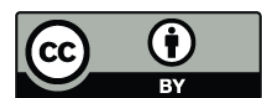

Correspondence to: L. Créton-Cazanave (lcretoncazanave@gmail.com)
In this paper, we will focus on the stakeholders' use of information issued by the French weather service "Météo France", relying on the data from our thesis research. The first section defines the main characteristics of the "classical approach". The second section exposes our pragmatic study of the warning process. Finally, our first results showing the interest of using the same framework for the study of all the stakeholders of the warning process will be discussed.

\section{Classical approach of warning}

In general terms, a warning consists in providing enough time for preventive actions (PA), before an event occurs. In a way, the warning process is a "ime trial", or a race against the phenomenon. To win this race, and be able to conduct PA, we need to anticipate and assess (making sense out of) the situation. One who do not understand what is about to happen, is unlikely to choose and take PA relevant for the specific situation. The classical paradigm rely on:

The linear model postulate that "time slips away", so the available time before a flood occurs is limited. Using the potential warning time, Carsell et al. (2004) for instance assume that some subprocesses have to be processed one after the other: data collection, evaluation, notification, decision making, and then, preventive actions. In spite of many criticisms (e.g. Pielke and Carbone, 2002), this linear model is still dominant, especially in the French warning policy.

(At least) two worlds: modernity and technobureaucracy gave us with some rules for the race, that rely on a strict separation between several worlds (Becker, 1984), caracterised

Published by Copernicus Publications. 


\section{Warning race \& classical postulate}
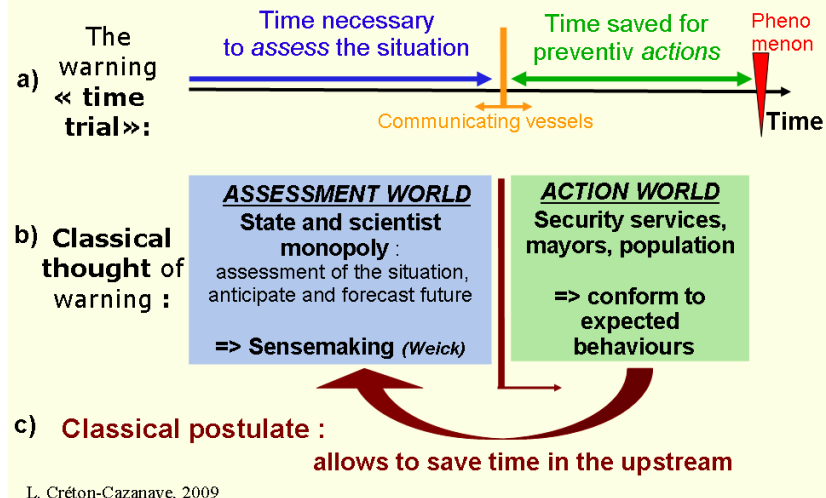

Figure 1. The warning "race" and the French postulate.

by: their prerogative (forecasting/decision making, for instance), their status (scientific/citizen), and their scale of action (national/local). It implies that the people of one world have similar ways to think or to act, and that they share the same interests. This is the so-called classical approach which distinguishes, at least, two worlds (Fig. 1b): 1) the assessment world: scientists and national institutions are the sole in charge of assessing the situation. 2) The action world: security services, local officials, citizens have the responsability of PA. Once scientists have provided information regarding the threat, they have to conform to expected behaviours (security plans).

And a postulate: Underlying this classical French approach of warning, we can point at a strong postulate: should people in charge of taking actions conform to expected behaviours, without wasting time trying to assess the situation by themselves, time should be available in the upstream for scientific assessment (Fig. 1c).

The most recent studies about flash-flood warnings underline the need for an integrated approach, relying on a closer connection between meteorological research and societal needs (e.g. Demuth et al., 2007; Stewart et al., 2004). Still this integrated approach postulates the existence of two separated worlds, which we question here.

\section{Pragmatic framework for warning studies}

Before leaning warning studies back against the classical postulate, we should take into account what people actually do, all along the warning process. We need to consider real stakeholders' practices. We chose to focus here on the way stakeholders use the meteorological information (MI), which is a real issue: weather forecasters are under a lot of pressure when they assess a situation since it could determine what to do next. During the flash flood warning process, each stake- holder uses this initial information, in one way or another: Do they use it for a further assessment of the situation? Do they use it for undertaking preventive actions?

\subsection{A pragmatic approach}

To consider stakeholders' warning practices, we propose to use the pragmatic sociology framework (Nachi, 2006).

Our work is inspired by the trivial question "what do people actually do?". Warning is a process. So, our central preoccupation is the warning being processed by stakeholders in context. The principles we take from pragmatic sociology infers an approach which is: 1) integrated (Montz and Gruntfest, 2002): warning must be considered from meteorological data acquisition to the warning response. That's why we consider that "stakeholder" means everyone who is concerned, from the weather forecasters to the riverside residents; 2) symmetric: in line with Sciences and Technology Studies, we don't make any hierarchy between scientific/non scientific knowledges or tools. That does not mean they are worth the same, but social scientists have to consider and treat them equally; 3) diachronic: we try to grasp the dynamic and the temporal dimension of the warning process; 4) characterised by a multi scales study area (national, regional, departmental, little towns and riversides residents), to better understand all the interactions in the Vidourle catchment.

\subsection{Case study and methodology elements}

In order to study how people actually use the MI along the warning process, we used interviews conducted in 20072008 as a part of a general study of flash-flood warning process in the Vidourle basin. These interviews were conducted with representatives of all stakeholders involved in the warning process: weather and flood forecasters and managers, state representatives in the département (le préfet) and chief of SIDPC (emergency manager at the département scale), mayors, riverside residents and shopkeepers, emergency services, rural policemen, and private company providing decision-making support to mayors. More than eighty interviews have been conducted, in different places: Paris, Toulouse, Aix-en-Provence, Nimes and in the Vidourle riverside municipalities. Indeed, if the Vidourle floods a little catchment, the warning process involves people from several parts of France (Fig. 2). Thus, this study reflects both a part of the French floods warning system, and some specific aspects of the social organisation in the Vidourle catchment.

We primarily asked stakeholders: "How do you concretely process the flash-flood warning?”. We were looking for: i) the kind of information/data received or sought, ii) kind of use of these informations (tools, interpretation frames), iii) what (or who) determines the value of the information, iv) impact of social interactions, v) How they do warn other people. 


\section{Geographic distribution of stakeholders}

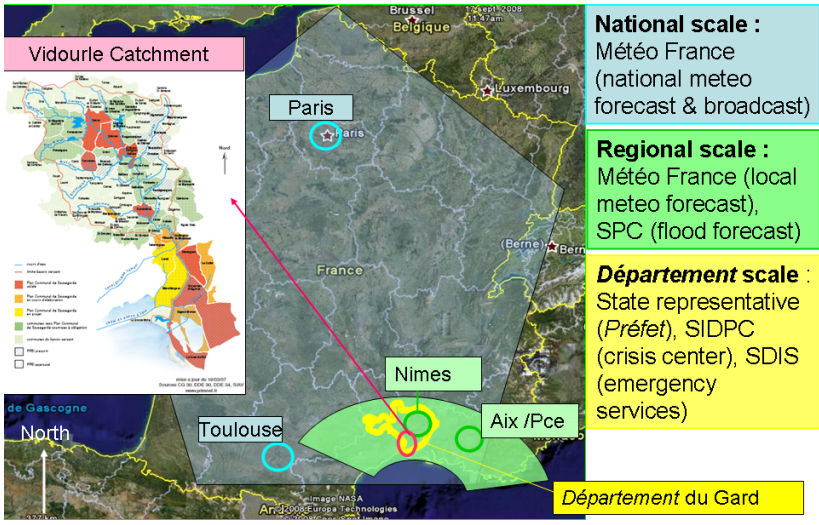

Figure 2. Many stakeholders, places and scales.

The following results rely on a qualitative analysis of fourteen interviews, chosen for their representativity of each scale and each kind of stakeholders.

Notice that Météo France issues several signals and informations. We will focus on the use of two of them: 1) the carte de vigilance, that pictures the forecast of dangerous hydrometeorological events for the next $24 \mathrm{~h}$, thanks to a colour code (green, yellow, orange, and red for worst events), at the départment scale. It is widely broadcasted (TV, Internet, radio, newspapers) 2) bulletins de précipitations, detailling the expected amount of precipitations for the next $24 \mathrm{~h}$, in relevant areas for hydrologists. The latter are only sent to flood forecasters.

\section{Results}

In order to present graphically our results, we use a two-bytwo matrix considering assessment on the first axis and PA on the other. It allows to compare what should be the stakeholders' use of MI according to the classical approach and the concrete manner stakeholders use MI (Fig. 3).

According to the classical postulate, there should be two ways of using MI: people from the assesment world (in blue) are expected to use MI to assess the threat, whereas people from the action world (in green) are only expected to use MI as a basis for the PA. Then we assigned to our fourteen stakeholders some qualitative coordinates, according to what they actually do with the MI: \{important/average/little/none\} assessment of situation and a lot of/several/a few/none PA. Finally, we placed our stakeholders in the matrix (red crosses). It appears that the stakeholders' practices debunk the classical postulate: most of them use the MI both to assess the threat and to undertake PA

\section{Warning practices $=$ one world $?$}

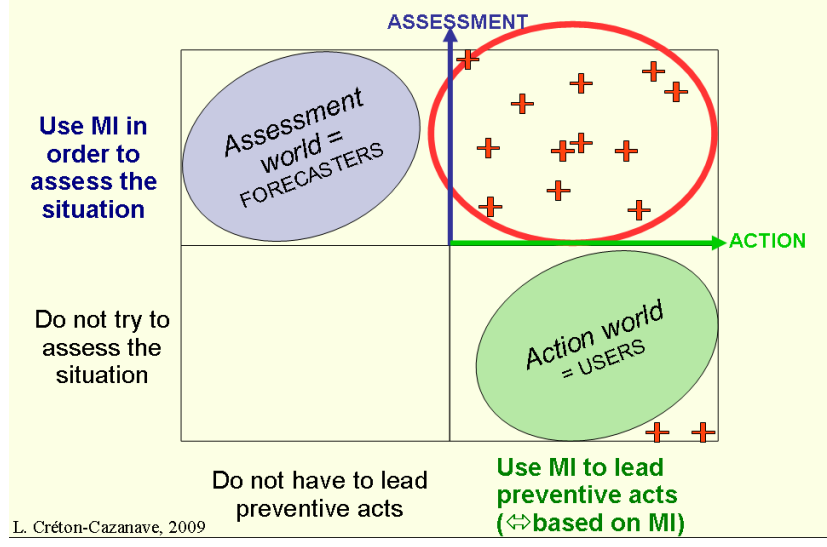

Figure 3. Warning practices: a base for integrated approach?

\subsection{No assessment out of action}

Assessment of the situation is always linked with action. Directly, as the forecasters draw cartes de vigilance, and TV and radio warnings. Indeed, to issue the cartes de vigilance, forecasters have to choose a colour for each département: green $=$ no threat, yellow $=$ threat for outdoor activities, orange $=$ threat for current activities, red $=$ extreme threat for people. This choice, in spite of the Météo France official discourse, does not rely only on a scientific assessment but is also a matter of decision making: both weather and hydro forecasters explained us how they actually consider political, economical and territorial issues drawing the cartes de vigilance. For instance, a previous missed warning or a conflict with security agencies, touristic periods, or special meetings such as the Grand Slam tennis tournament "Roland Garros" may be a substantial part of the choice. More indirectly, the forcasters take into account, all along the assessment process, what they know (or believe) about PA and associated constraints. For instance, choosing the orange colour for a département means that the rescue operational center (CODIS) has to be warned, the préfet is supposed to open the emergency operation centerr, radio France Bleu Gard Lozre is supposed to follow a strict broadcast plan and people are supposed to adapt their behaviours. The forecasters we met were fully aware of their choices' consequences. And we did not meet any forecaster who decline to make choices and to be a part of the preventive action.

\subsection{No action without assessment}

It seems to be impossible for people to undertake relevant PA without making sense out of the situation. For instance, local authorities (mayors and rural policemen) systematically try to assess by themselves the situation. Indeed, MI informs them about the general situation of the département, but often 
fails to assess their local threat. Yet, PA (to move property, to close schools or highways, to evacuate populations, to shut down factories) may have high economic, politic or social costs. Local authorities are thus very careful, and seek, by many ways, a really accurate assessment of their local situation. As a mayor said:

"I received the carte de vigilance ... I got my boots on, and I walked to the river... to have MY quick look to Vidourle... Then, my team and I tought we could wait for children to leave the school before closing the roads."

And a rural policeman told us: "I know Vidourle for a long time... Sometimes, Vidourle 'tells' me 'it comes'... and, when my family is threatened, I trust this feeling more than the official warning!"

Citizens whose preventive action consists in moving their car to higher places still try to assess their situation: they call the neighbourhood or relatives, or trusted local authorities, in order to know what happens (waterlevel, precipitations upstream, for instance).

The two exceptions are very specific: we met a woman who "waterproofed" her house after the 2002 flood! When she is aware of an "orange vigilance", she pushes the button linked to her pneumatic doors and windows, and the house cannot be flooded anymore. She does not care if a flood actually occurs or not. The other one is a new rural policeman, who does not know much about Vidourle and floods. So he does exactly what the mayor wants him to do, without trying to have an opinion about what is happening or not.

\subsubsection{A common study framework}

These results are consistent with previous integrated researches (e.g. Drabek, 1999; Morss et al., 2005, 2008). But, they also suggest that the practices of warning stakeholders are not always consistent with the postulate of two worlds: in our case, all stakeholders both assess the situation and undertake PA. This new outcome has a first methodological consequence: we can (must) study all stakeholders with the same analysis framework. Despite their various tools or capacities, a common framework would allow to compare practices. Additional studies, in different places and on different warning systems, would be useful to assess the validity of this finding out of the Vidourle basin.

Furthermore, the broad results of this study give us some clues about the real warning practices, and highlight some questions that should be studied in a more pragmatic way: 1) kind of interpretation frameworks mobilized to assess the situation 2) kind of stakeholders' connections with action, and kind of prises they have to reduce flood impact (prise is a French concept, used in warning studies (Chateauraynaud and Torny, 1999), that could be translate by "grip" in a metaphorical way, or "affordance" (McGrenere and Ho,
2000) except that prises implies a human habilities to create them); 3) How do the stakeholders process a scales changing on available informations, i.e. how they try to make the MIs' scales consistent with their own scales, in order to assess the situation and to be able to undertake the relevant PA.

\section{Conclusions}

It appears that, in the Vidourle basin, the assessment world and the action world do not exist anymore when we study the concrete manner stakeholders process the warning. It does not mean that stakeholders are interchangeable, but we should study their practices within the same framework, in order to identify the real differences/similarities in their activities. Since the practicess of stakeholders appear to be comparable, it becomes even more suitable to study them in a deeply integrated approach. Pragmatic Sociology seems to be a relevant frame for this new kind of warning studies, since this approach allows to observe real practices, that are missed with the classical approach.

Acknowledgements. This thesis work relies on a grant from the Région Rhône Alpes, and takes place in the Observatoire Hydro-météorologique Cévennes Vivarais (OHMCV). The author would like to thank J.-C. Gaillard and I. Ruin for their help and the reviewers for their helpful remarks.

Edited by: F. Stel and D. B. Giaiotti

Reviewed by: three anonymous referees

\section{References}

Becker, H. S.: Art worlds, University of California Press, 1984.

Carsell, K. M., Pingel, N. D., and Ford, D. T.: Quantifying the benefit of a flood warning system, Nat. Hazards Rev., 5, 131140, 2004.

Chateauraynaud, F. and Torny, D.: Les sombres précurseurs: une sociologie pragmatique de l'alerte et du risque, EHESS, 1999.

Demuth, J. L., Gruntfest, E., Morss, R. E., Drobot, S., and Lazo, J. K.: WAS*IS: Building a Community for Integrating Meteorology and Social Science, B. Am. Meteorol. Soc., 88, 1729-1737, http://dx.doi.org/10.1175\%2FBAMS-88-11-1729, 2007.

Drabek, T. E.: Understanding Disaster Warning Responses, The Social Science Journal, 36, 515-523, 1999.

Drobot, S. and Parker, D.: Advances and challenges in flash flood warnings, Environmental Hazards, 7, 173-178, 2007.

Hornus, H. and Martin, X.: Retour d'expérience sur la vigilance crue et son intégration dans le dispositif de crise lors des événements pluviaux du 6 au 9 septembre 2005 dans le gard et l'hérault., Tech. rep., IGE, MEDD, 2005.

McGrenere, J. and Ho, W.: Affordances: Clarifying and evolving a concept, in: Graphics Interface, 179-186, 2000.

Montz, B. E. and Gruntfest, E.: Flash flood mitigation : recommendations for research and applications, Environmental Hazards, 4, 15-22, 2002.

Morss, R. E., Wilhelmi, O. V., Downton, M. W., and Gruntfest, E.: Flood risk, uncertainty, and scientific information for decision making, BAMS, 86, 1593-1601, 2005. 
Morss, R. E., Demuth, J. L., and Lazo, J. K.: Communicating uncertainty in weather forecasts: A survey of the US public, Wea. Forecast., 23, 974-991, 2008.

Nachi, M.: Introduction à la sociologie pragmatique: vers un nouveau "style" sociologique?, Armand Colin, 2006.

Pielke, R. and Carbone, R. E.: Weather impacts, forecasts, and policy, BAMS, 83, 393-406, 2002.
Sorensen, J. H.: Hazard Warning Systems : Review of 20 years of progress, Nat. Hazards Rev., 1, 119-125, 2000.

Stewart, T. R., Pielke, R. J., and Nath, R.: Understanding user decision making and the value of improved precipitation forecasts, B. Am. Meteorol. Soc., 85, 223-235, 2004. 